\title{
Assignment of the gene for a ubiquitin- conjugating enzyme (UBE2I) to human chromosome band 16p 13.3 by in situ hybridization
}

\author{
M. Tachibana,' N. Iwata, ${ }^{2}$ A. Watanabe, ' Y. Nobukuni, ${ }^{3}$ B. Ploplis, ${ }^{1}$ \\ S. Kajigaya ${ }^{2}$ \\ 'Laburatory ol Molceular (ienelics. Natinnal Instilute on Deafness and Olter Cummunicatiun Disurders. NIII. Ruckulle MI): \\ : Hematologs: Brask'h. Natiunal Hean. Lung and Blood Insurute. NIII. Betheeda. MD (IISA):

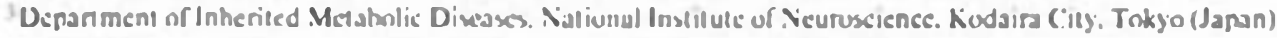

\section{Pationale and signifleance}

Wic have recently cloned a cDNA enconding a protein which interacts with a tmonscriplion factur. WITF (Micruphihalmiaassociatcd transcription factur). using I he tcast I wo-hṣthrid system (lwata et al.. in nreparytiun). The predicted protein called UBE2) (GcnBank: (145.328) is - $60 \%$ homologous to a ubiquilin-conjugating enz!me (l:2) of Saccharomb'ces cerrevisiue' UBC.? (Scufert ct al. 1994) and that of Schizosnccharomice's jmmlw. Hus S (Al-Kohdair. ct al. 1994). Une of the functions of a uhiquitin-conjugating s!'stem is 10 degrade transcription faclurs such as MATa? (Hochstrasser and Varharsk!. 1990) and Cient (Komizer el al.. 1994). MITF is a transcription faclur which is involved in melanocytc differentiation (Tachibana el al.. 1994. 1996). Mutations of the MITF genc apme:ar I cause W'aardcuburg syndrome type 2 (WS2: MIM19.3510) in patients from some families (Tasishehiji et al.. 1995: Nobukuni cl al.. 1996). Given the assexcialion between UBL:I and MITI: gene products. We speculate that mutations of the UBEZI gene ma! cyuxe WS? ur similar diseases. W'c here localized the UBE?I genc un chromosome 16 band pl3.3. Among scveral discascs mapped to $16 \mathrm{p} 13.3$. the autosomal dominant congenilal cataract with microphthalnia (Yokoyama til al. 1992: MIM 156850) is the one most likely (o) involve a mutation of the UBE2l genc. since microphthalmia can he caused by mutations of the MITF homolog in mice (Slcingrimisson $\mathrm{ct}$ al.. I $199 \mathrm{~A}$ ). W'c

Recived IFehruary 1996: revision accepted 29 July 1996.

Requed renrints frumn Dr. Musayushi Tachibana. NIIX'D. I Research Coun. Rnihsilk MII) 20850 (USA). Ielephone: 301-202-3033: (ax: 101-102-4989: email: miahibute nur.nidod nih par. are now analyzing the possible nutation of the LBE?I genc in an individual showing congenital sataract with micruphthalmia (Yokoyama et al.. 1992).

\section{Materials and mothods}

Ilunian meraphaec cells were necpared fium phytuhemugeglutimn-simu. laled lymnheryes. Punfied DNA from a PI clone containing the U!BR:2l gene was laheled with dignoigenin-dl ITP hy nick Iranslation and used as a probe. In untravlur HISH. digoxigenin.laheled pmohe was enmbinad with sheared human D.S.A. and hopridized lu melaphase chrumosomes in a soluliun cuntaining $50 \%$ formamide. 10\% dexiran sulfate and ? . SSC, and Jercited with huurexerin-tunjugaled anild iguxigen in antihodits as descrihed previnusly (Stnkke el al., 1995). Chron)momes were then cuunter-stainid with prupidium iudide. For iwo-colne FiSll a hintin laheler nrothe specific for the heterechrumatic region uf chrumuxume 16 was employed. Chromosume 16 specificity "are confirmed by the cohsihridization of marker DI6S4?2 \{D:. Valentine. unpullished dala). The ponte was conhyhridized with l:AF:21 pmhe and detciled by avidin-Teras red. Chrumusomes were then cuunterstained hy d:6-diamidinot-2-phenylindole

Pross name IIBF:-21-PI/903?

Pruts ispe genumic DNis

lisert siac - 82 ih

linser l'I nhage

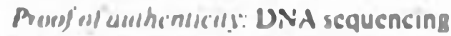

(irne referense Walanathe et al. (1996). I wuta st ul. (in preparation) and this repon

\section{Results}

One-color I:ISH resulted in spacific labeling of the distal shon arm of a group $E$ chromosonc. Twercolur experiments resulted in the specific labeling of the shor arm of chromosomes which are cirlabeled with ine prohe specific to chromo-

\section{KARGER Eomallangerpulanges} ras - गI का ux 1: is

(. 1907 S. Kayส AG. Haul

This arick is al w acceruble online al:

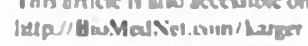




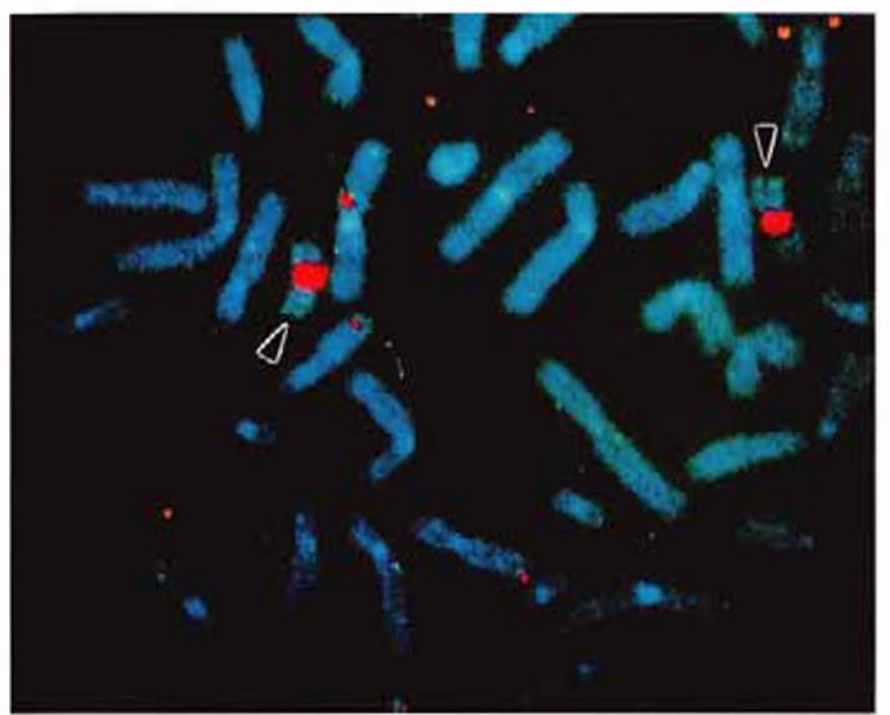

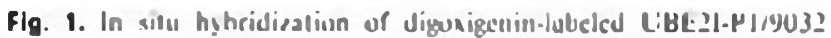
probe to humun metuphase cells resulted in specific laheling at the $\mathrm{p} 1.3$. region of chroumosume 16 (gescen signals. arruw heads). Nute that the chromu some is labeled with a ponhe speceine for the hetenichenm.stic region of chro mosome 16 (pink siznuls). some 16 (1Fig. 1). Measurements of 10 specifically Mrhridis:d chromosome $16^{\circ}$ s demonstrated that the USF.? menc is lexated at a position which is $98 \%$ of the distance from the cenirnmer to the telonicre of chromusume arm I fp. an an:a that corre sponds 10 band $16 \mathrm{pl} 3.3$.

\section{L.oculion: $|6 p| 3.3$}

No. of cells examinerl: 80

Ne. of cells with spresfic signals: 68

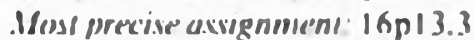

l.owestion of hurkermund signals (sites uph > ? signals): none whicenicd

Note: I)uring the revicu of the manuscript. a cDViA for UHI:2I was cloned from human letal-brain libran and the gelle was mapped (Watanabe el al.. 1996).

\section{Acknowledgements}

We thank De. W Valenline for his lachnieal assistunce and fur ho glll of

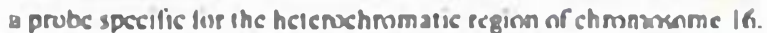

\section{Roferences}

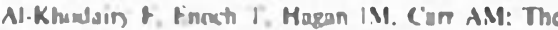

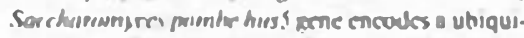
lin omjureling ens nie reyuirod fur numbl mile sic J Cell Sci I0R: 775 - 886 (1995)

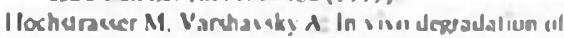
a iranscriptional negulatur. the yeasl o? ieneteruil Cell 61:607-70R 11090)

Knmiszer D. Rahas) A. Kullha RT, Finh (ik Krouluter desradation of the iranscription factop Gint. E.MBO \& 1 3:6021-6010 (1994).

Nubukuni Y. Walanabe A. Takeda K Skapka II. Tachl. hina .I: Analexes of loss-of-function mutations of the MII gene su Besis that haploin auficicacy is a

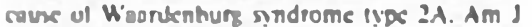
hum (kne $59 \cdot 70-83$ ) 1 1 y.40).

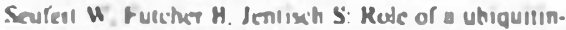

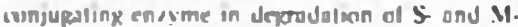
phace csalins Nalue $173: 78-81$ (19yd)
Sicngrimsson E. Moore NJ. Lamoneux Ml. I ernt. U.Amare. Burle, SK, Zimpine IXS. Skow I.C Hudpkinxin CA. Amheilep H. Copdand NC. Jer bins NA: Mulcrulap bass of mouk mirnephinal. mine ImIs mulesium holps itplain theip develos

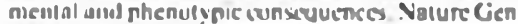
ल 8.256 .263 (1 497)

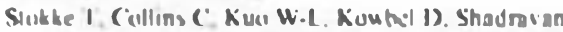
F. Tannes M. Kallioniesni A Kalliullemi ()-P Pinkel D. Desien L and Giras JU: $\wedge$ physical map of chromosome 20 essabliched uxing numrevent in sim hybridization IrISIII and digital image analy. is. Genomies 26:1 34 137 (1999).

Tachibana M. Peres-Jurado LA. Nakavama A. Ilodg kenson CA. LI X. Schncider M. Miki T. Fex J. Francke U. Amheiter II: Cloning of MITI. the liuman homoles of the mouse micmphehaloilo genc. and assigonmi lo human chromusome 3 .

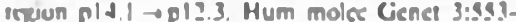
เร7(1บบd).

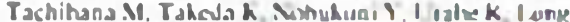
JC. Mejers RA. Aarman A Mili I: Feyara: expression of MITT a ene for Hastenhure s:odrome lape 2. convens fihroNaste to sells wilh

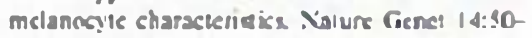
94. 1996.

lasubehis M. Veuion VE. Read AP Kasnenhurs syndrome type a caused by mulations in the haman micrinhihalmid (MITF) grec. Nature Gonsi 18:231-252(1949)

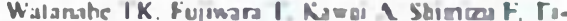

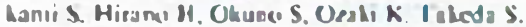
Shinada Y, Nopala W Vakumi A. I iluhashi t.

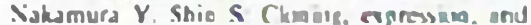

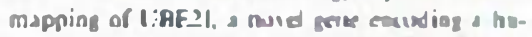

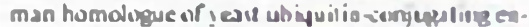
nmos which are critical fol mogulating tbe adl eyele. Cylogenel Col Creod 79:16-80 II 9061

Yokog ama Y'. Narahara K. Tuvii K. Nimmijas Seam I: Autosomal domioanl congenilal cilara's and microphihalmia ascocialed with (amilal (2:-16) inanslocalion. I lum Gener 90:197-1 18(1992) 